rethrombosis treatment is usually continued with oral anticoagulants. Streptokinase is antigenic and the antibody level rises appreciably in the days following an infusion. Allergic reactions are rather frequent, but can usually be controlled with corticosteroid or antihistamine drugs.

\section{Urokinase}

The allergic complications of streptokinase therapy do not occur with urokinase, a direct activator of plasminogen which can be extracted from human urine. Urokinase is not antigenic in man, and the absence of circulating antibody means that the effects of the first dose can safely be predicted according to body weight. It has a proved thrombolytic potential and has been investigated in the treatment of pulmonary embolism. ${ }^{32}$ Nevertheless, large quantities of human urine have to be used to obtain adequate supplies and hence no trial of systemic urokinase in venous thrombosis has been carried out-though local treatment may be of value. ${ }^{33}$

The precise place of fibrinolytic therapy in relation to anticoagulants and surgical procedures has yet to be defined. The most important consideration at present is to ensure that its use is limited to those with thrombi demonstrated and followed by objective methods, so that valid information is obtained.

\section{Prophylaxis}

In patients with a very high risk of pulmonary embolism, particularly the elderly in bed following trauma or tissue necrosis, prophylactic oral anticoagulants are effective in reducing mortality from thromboembolism. ${ }^{34} 35$ After general surgery the effects of encouraging mobility of the legs, raising the foot of the bed, and providing firm external support, before, during, and after operation have been investigated using the ${ }^{125}$ I-labelled fibrinogen method. The incidence of thrombosis was reduced in those over 60 years, but postoperative thrombi were still found in at least $24 \%$ of those examined. ${ }^{36}$

An antithrombotic effect has been associated with the intravenous administration of dextrans, particularly those with an average molecular weight of 70,000 , which reduce plasma viscosity and change platelet behaviour. ${ }^{37-39}$ There have been many encouraging clinical reports, while objective studies ${ }^{4041}$ have tended to confirm their effectiveness. Dextrans are contraindicated in any condition in which further expansion of plasma volume may overload the circulation, and this includes many patients in the medical wards.

In urgent need of further investigation are the drugs which alter platelet behaviour ${ }^{424}$ and those which increase the spontaneous activator of fibrinolysis in the plasma. ${ }^{44}$

\title{
Surgical Management
}

\author{
G. E. MAVOR* M.D., CH.M., F.R.C.S.ED.
}

It is useful to classify deep vein thrombosis into either peripheral or iliofemoral. The termination of the profunda femoris vein (about $5 \mathrm{~cm}$. below the groin) is the most convenient site to take as the boundary between these segments. $^{45}$ Nevertheless, the early stages of clot formation are not necessarily restricted to one or other of these segments, since both of them are often involved simultaneously. ${ }^{4-49}$ How often peripheral deep vein thrombosis extends proximally into the high segment or gives rise to pulmonary emboli is uncertain, though probably such complications are rare. On the other hand, iliofemoral venous thrombosis-though less commonis more insidious, more dangerous, and more damaging in its consequences. Moreover, this type of thrombosis is usually complicated by propagation distally. Pulmonary embolism, of ten major or fatal, occurs in about half of all cases of high segment thrombosis, while if venous occlusion occurs serious venous insufficiency is usually inevitable. ${ }^{49}$

\section{Peripheral Segment Thrombosis}

Too much significance is still placed on the peripheral segment-and particularly on the calf veins-as an initial site of thrombosis. Despite the traditional belief that intravenous clotting spreads continuously from the lower segment to the upper one, recent studies do not confirm that this is common. Thus in a combined total of 420 special necropsy studies N. M. Gibbs ${ }^{47}$ and S. Sevitt ${ }^{50}$ were unable to find a single instance of this type of spread. Likewise, in a personal series of 257 cases of iliofemoral venous thrombosis, propagation had occurred from peripheral to iliofemoral segment in only 24 instances. ${ }^{49}$ Furthermore, before the peripheral segment can be incriminated as a source of embolism, phlebography must

* Consultant Surgeon, Aberdeen Royal Infirmary, Aberdeen. be used to prove that the iliofemoral segments are clear of nonocclusive clot. The presence of acute signs of peripheral deep vein thrombosis, or direct evidence of clot formation from the results of venography, or of the ${ }^{125}$ I-tagged fibrinogen technique $^{11}$ does not remove the need to investigate the iliofemoral segments.

Past failures to prevent pulmonary embolism by ligating the superficial femoral vein below the profunda termination have been due to clot formation in the iliofemoral segment. Nevertheless, if it is confirmed that the peripheral segment is the only site of clot formation, this operation is a satisfactory procedure for controlling embolism. ${ }^{51}$ At operation noninvolvement of the iliofemoral segments should be confirmed radiologically. Ligation of the deep vein below the profunda termination is not complicated by swelling of the leg, as there are adequate " run-around" collateral channels. Nevertheless, destruction of the valves may occur and lead to one type of postphlebitic damage. ${ }^{45}$

\section{Iliofemoral Venous Thrombosis}

In iliofemoral venous thrombosis thrombus formation begins in this segment. There may be extensive formation without occlusion of the veins, and hence there is a severe risk of pulmonary embolism. ${ }^{352}$ When occlusion does occur acute venous insufficiency develops, as the venous collateral vessels are inadequate to deal with the venous return. Iliofemoral venous thrombosis with occlusion represents the most serious therapeutic challenge in deep-vein thrombosis. Since even with present day anticoagulant regimens the mortality rate of pulmonary embolism is $30 \%,{ }^{53} 54$ more attention should be paid to clearing this segment, and venous thrombectomy without ligation or plication should always be considered. 


\section{Venous Thrombectomy}

The best results from venous thrombectomy are achieved using radiographic control and the sapheno-femoral technique with topical heparin. ${ }^{4549}$ In cases when the clot is nonocclusive, the patient presents with pulmonary embolism without leg signs, and the diagnosis has been made by phlebography, thrombectomy will give excellent results in producing complete clearance of the segment, thereby controlling embolism. ${ }^{45}$ When occlusion is complete and venous insufficiency is present, the aim of thrombectomy is to clear the segment, as only in this way will the risk of major embolism be removed and acute and chronic venous insufficiency of the poor-collateral-circulation type overcome. ${ }^{49}$ When embolism has occurred and unilateral occlusion is present, bilateral visualization of the segments is required before operation, as the contralateral segment or inferior vena cava may contain non-occlusive clot and be the source of embolism. In a series of 112 cases of occlusive thrombus phlebographic studies showed that complete clearance of the segment was obtained in about $64 \%$ of all the cases, and in $75 \%$ when surgery was undertaken within 48 hours of the onset of complete occlusion.

With complete clearance both recurrent embolism and early and late rethrombosis are uncommon. With incomplete clearance these complications increase in incidence and detract from the value of the procedure (Tables I and II). If embolism has not occurred in a patient with iliofemoral venous thrombosis, venous thrombectomy does not increase the risk of embolism. If, on the other hand, embolism has occurred preoperatively (as it has in about half of all cases) the risk of postoperative embolism is higher, reaching $19 \%$ as regards non-fatal embolism and $6 \%$ as regards fatal (Table III). This mortality is almost always associated with phlebographic evidence of incomplete clearance of the segment at operation. Nevertheless, the decision to operate should not be affected by the presence of embolism.

TABLE I.-Rethrombosis After Venous Thrombectomy

\begin{tabular}{ll|c|c|c|c}
\hline & & \multicolumn{2}{|c|}{$\begin{array}{c}\text { Early Rethrombosis } \\
\text { (within 14 days) }\end{array}$} & \multicolumn{2}{c}{$\begin{array}{c}\text { Late Rethrombosis } \\
\text { (3 months-5 years) }\end{array}$} \\
\cline { 3 - 5 } \cline { 5 - 6 } & Cases & Rethrombosis & Cases & Rethrombosis \\
\hline $\begin{array}{ccc}\text { Complete clearance } \\
\text { Partial clearance }\end{array}$ & $\ldots$ & 61 & $7(6 \mathrm{P})$ & 18 & 4 \\
\hline
\end{tabular}

All figures based on phlebographic evidence of rethrombosis.

P denotes partial rethrombosis.

TABLE II.-Control of Embolism by Iliofemoral Venous Thrombectomy (143 Cases)

\begin{tabular}{|c|c|c|c|c|c|c|}
\hline & & & & $\begin{array}{l}\text { Complete } \\
\text { Clearance }\end{array}$ & $\begin{array}{c}\text { Partial } \\
\text { Clearance }\end{array}$ & Failure \\
\hline $\begin{array}{l}\text { Total . . } \\
\text { Further embolism } \\
\text { Fatal embolism }\end{array}$ & $\begin{array}{l}\ldots \\
\ldots\end{array}$ & $\ddot{x}$ & $\ddot{x}$ & $\begin{array}{c}38 \\
(13 \%) \\
0\end{array}$ & $\begin{array}{c}52 \\
12(23 \%) \\
4(8 \%)\end{array}$ & $\begin{array}{c}23 \\
8(35 \%) \\
3(13 \%)\end{array}$ \\
\hline
\end{tabular}

Figures based on 3 months post-operative follow-up.

Two of seven deaths followed caval ligation.

TABLE III.-Pulmonary Embolism Following Venous Thrombectomy (257 Cases)

\begin{tabular}{|c|c|c|c|}
\hline \multirow{2}{*}{\multicolumn{2}{|c|}{ Pre-operative }} & \multicolumn{2}{|c|}{ Post-operative } \\
\hline & & Non-fatal & Fatal \\
\hline $\begin{array}{l}\text { Embolism present } \\
\text { No embolism }\end{array}$ & $\begin{array}{l}127 \\
133\end{array}$ & $\begin{array}{r}23(19 \%) \\
5(4 \%)\end{array}$ & $\begin{array}{l}7^{*}(6 \%) \\
1(1 \%)\end{array}$ \\
\hline
\end{tabular}

Figures based on 3 months post-operative follow-up

Contraindications to venous thrombectomy relate to the patient's general condition-for example, advanced malignancy, severe intercurrent disease, or severe obesity-or to local factors such as groin infection, or an already useless leg, as in hemiplegia. As delay after occlusion reduces the chances of complete clearance, it is doubtful whether thrombectomy is indicated 72 hours or more after complete occlusion develops except in certain circumstances. These circumstances relate to serious venous insufficiency approaching venous gangrene or to involvement of the vena cava with its risk of major embolism. In the former instance clearance of the common femoralexternal iliac system providing direct venous collateral drainage via the ascending lumbar vein is a justifiably limited aim, especially if thrombolytic therapy is not available. In most cases the result is much superior to the severe venous insufficiency resulting from extensive obliteration of the segment.

\section{Caval Thrombectomy}

Venous thrombectomy via the inferior vena cava is indicated in severe venous insufficiency approaching gangrene, particularly if the iliofemoral occlusion is bilateral. Early and aggressive surgery is indicated in such severe cases and holds out the only chance of arresting the disease and its consequences. Another indication is phlebographic evidence of clot in the vena cava, particularly if this is associated with pulmonary embolism, ${ }^{49}$ and thrombectomy via the common femoral vein has not produced satisfactory clearance, as is usually the case.

\section{Caval Ligation}

It needs emphasizing that the aim of surgery in iliofemoral or caval venous thrombo-embolism is to control embolism and to restore patency, so that function is maintained. In general, therefore, interruption of the main venous channels above the profunda termination is to be avoided if possible, and the routine use of such techniques as ligation and plication will lead inevitably to serious morbidity without necessarily controlling embolism. ${ }^{495}$ Nevertheless, in some long-standing or recurrent cases of serious thrombo-embolism iliac or caval ligation may still be indicated to try to control embolism and save life. In such cases thrombectomy is usually unsatisfactory because of the duration of the disease. Following ligation of the vena cava there is a serious risk of venous gangrene. Moreover, even though ligation is proximal to all known clot, embolism may occur from fresh thrombus formed proximal to the point of ligation. In the surgical management of over 300 cases of iliofemoral venous thrombo-embolism, caval ligation has been carried out in seven instances with a fatal outcome in four.

\section{Surgery in Pulmonary Embolism}

Successful surgical intervention in pulmonary embolism (whether associated with overt signs of venous thrombosis in N the legs or not) depends entirely on correctly localizing the site of venous thrombosis. For the peripheral segment this is best achieved by the ${ }^{125}$ I-labelled fibrinogen technique ${ }^{11}$ rather than by phlebography. In the iliofemoral segment, on the other hand, phlebography is much more satisfactory. ${ }^{49}$ It should also be remembered that in iliofemoral venous thrombosis, whether non-occlusive or occlusive, embolism is a frequent complication, while in peripheral thrombosis embolism is much less frequent and much less serious. Hence it is always essential to know the condition of the iliofemoral segments in planning the surgical approach.

\section{Streptokinase Therapy}

Experience with thrombolytic therapy suggests that streptokinase is to be preferred to urokinase. ${ }^{31}{ }^{33}$ Lysis with clearance is readily produced in thrombus completely occluding the iliofemoral segment even with clot known to be 30 days old. ${ }^{33}$ 
Moreover, giving high doses into the area of the clot is probably better for producing lysis than systemic administration. ${ }^{56}$ In some cases, however, despite careful anticoagulant cover with continuous heparin infusion and warfarin, it is difficult to prevent rethrombosis. There is no doubt that streptokinase is a drug of great promise in the effective therapy of venous thrombo-embolism. Some aspects of its use, however, such as the risk of rethrombosis, require clarification. At the present time it seems particularly useful in seriously ill patients with late or recurrent iliofemoral thrombo-embolism. Venous surgery may be precluded in these patients, and, because it is undertaken so late, it is often unavailing. In patients with thrombo-embolism of shorter duration streptokinase seems likely eventually to supersede venous thrombectomy as the treatment of choice.

\section{REFERENCES}

1 McLachlin, J., Richards, T., and Paterson, J. C., Archives of Surgery, 1962, 85, 738 .

2 Gibbs, N. M., British fournal of Surgery, 1957, 45, 209.

${ }^{3}$ Sevitt, S., and Gallagher, N., British fournal of Surgery, 1961, 48,

+ Dos Santos, R., fournale Internationale de Chirurgie, 1938, 6, 625.

5 Bauer, G., Acta Chirurgica Scandinavica, 1940, 84, Suppl. No. 61.

- Thomas, M. L., and Fletcher, E. W. L., Clinical Radiology, 1967, 18, 399.

' DeWeese, J. A., and Rogoff, S. M., Surgery, 1963, 53, 99.

${ }^{3}$ Hobbs, J. T., and Davies, J. W. L., Lancet, 1960, 2, 134

'Atkins, P., and Hawkins, L. A., Lancet, 1965, 2, 1217.

${ }^{10}$ Nanson, E. M., Palko, P. D., Dick, A. A., and Fedoruk, S. O., Annals of Surgery, 1965, 162, 438.

${ }^{11}$ Flanc, C., Kakkar, V. V., and Clarke, M. B., British fournal of Surgery, $1968,55,742$.

${ }^{2}$ Negus, D., Pinto, D. J., Le Quesne, L. P., Brown, N., and Chapman M., British 7ournal of Surgery, 1968, 55, 835.

${ }_{13}$ Strandness, D. E., Schultz, R. D., Sumner, D. S., and Rushmer, R. F., American fournal of Surgery, 1967, 113, 311 .

1. Sigel, B., Popky, G. L., Wagnewr, D. K., Boland, J. P., Mappe, E. McE., and Feigel, P., Surgery, 1968, 64, 332.

${ }_{15}$ Evans, D. S., and Cockett, F. B., British Medical fournal, 1969, 2, 802.

${ }^{16}$ Browse, N. L., Thomas, M. L., Solan, M. J., and Young, A. E., British Medical fournal, 1969, 3, 382.

${ }_{17}$ Kakkar, V. V., Howe, C. T., Flanc, C., and Clarke, M. B., Lancet, $1969,2,230$.

18 Hunninghake, D. B., and Azarnoff, D. L., Archives of Internal Medicine, 1968, 12i, 349 .

19 Jick, H., Sloane, D., Borda, I. T., and Shapiro, S., New England fournal of Medicine, 1968, 279, 284.

${ }^{20}$ Reid, H. A., and Chan, K. E., Lancet, 1968, 1, 485.

${ }^{21}$ Bell, W. R., Pitney, W. R., and Goodwin, J. F., Lancet, 1968, 1, 490.

${ }^{22}$ Sharp, A. A., Warren, B. A., Paxton, A. M., and Allington, M. J., Lancet, 1968, 1, 493.

${ }^{23}$ Kakkar, V. V., Flanc, C., Howe, C. T., O'Shea, M., and Flure, r. r., British Medical Fournal, $1969,1,806$.

2t Pitney, W. R., Bray, C., Holt, P. J. L., and Bolton, G., Lancet, 1969, $1,79$.

${ }^{25}$ Sherry, S., Fletcher, A. P., and Alkjaersig, N., Physiological Reviews, $1959,39,343$.

${ }^{28}$ Kowalski, E., Seminars in Haematology, 1968, 5, 45.

${ }_{27}$ Flute, P. T., fournal of Clinical Pathology, 1964, 17, 333.

${ }_{28}$ Verstraete, M., Vermylen, J., Amery, A., and Vermylen, C., British Medical fournal, 1966, 1, 454.

${ }^{29}$ Robertson, B. R., Nilsson, I. M., Nylander, G., and Olow, B., Acta Chirurgica Scandinavica, 1967, 133, 205. so Kakkar, V., Howe, C. T., Laws, J. W., and Flanc, C., British Medical fournal, 1969, 1, 810 .

${ }^{31}$ Mavor, G. E., Bennett, B., Galloway, J. M. D., and Karmody, A. M., British fournal of Surgery, 1969, 56, 564

32 Sherry, S., Annals of Internal Medicine, 1968, 69, 415.

${ }^{33}$ Mavol, G. E., Ogston, D., Galloway, J. M. D., and Karmody, A. M., British fournal of Surgery, 1969, 56, 571.

3. Sevitt, S., Proceedings of the Royal Society of Medicine, 1968, 61, 143.

35 Sevitt, S., and Gallagher, N. G., Lancet, 1959, 2, 981.

30 Flanc, C., Kakkar, V. V., and Clarke, M. B., Lancet, 1969, 1, 477.

37 Bennett, P. N., Dhall, D. P., McKenzie, F. N., and Matheson, N. A., Lancet, 1966, 1, 1001

${ }^{38}$ Cronberg, S., Robertson, B., Nilsson, I. M., and Niléhn, J. E., Thrombosis et Diathesis Haemorrhagica, 1966, 16, 384.

s9 Bygdeman, S., Acta Chirurgica Scandinavica, 1968, Suppl. No. 387, p. 44.

10 Johnsson, S. R., Bygdeman, S., and Eliasson, R., Acta Chirurgica Scandinavica, 1968, Suppl. No. 387, p. 80

${ }^{11}$ Lambie, J., Barber, D., Dhall, D. P., and Matheson, N. A., British fournal of Surgery, 1969, 56, 619.

4 Hampton, J. R., Harrison, M. J. G., Honour, A. J., and Mitchell, J. R. A., Cardiovascular Research, 1967, 1, 101.

43 O'Brien, J. R., Lancet, 1968, 1, 779.

44 Fearnley, G. R., and Chakrabarti, R., Fournal of Clinical Pathology, $1969,22,368$

45 Mavor, G. E., and Galloway, J. M. D., Surgery, Gynecology and Obstetrics, 1967, 125, 561.

16 McLachlin, J., and Paterson, J. C., Surgery, Gynecology ana Obstetrics, 1951, 93, 1.

${ }^{47}$ Gibbs, N. M., British Fournal of Surgery, 1957, 45, 209.

18 Sevitt, S., American fournal of Medicine, 1962, 33, 703.

4 Mavor, G. E., and Galloway, J. M. D., British fournal of Surgery, $1969,56,45$.

so Sevitt, S., in Modern Trends in Accident Surgery and Medicine, ed. by R. Clarke, F. S. Badger, and S. Sevitt, P. 247, 1959. London, Butterworth.

${ }^{31}$ Mavor, G. E., Galloway, J. M. D., and Karmody, A. M., Proceedings of the Royal Society of Medicine, 1969, in press.

52 Mavor, G. E., and Galloway, J. M. D., Lancet, 1967, 1, 871.

${ }_{53}$ Barker, W. F., Surgery, 1959, 45, 198.

54 Donaldson, G. A., Linton, R. R., and Rodkey, G. V., New England fournal of Medicine, 1961, 265, 208.

${ }_{55}$ De Meester, T. R., Rutherford, R. B., Blazek, J. V., and Zuidema, G. D., Surgery, 1967, 62, 56.

so Karmody, A. M., Galloway, J. M. D., and Mavor, G. E., British Fournal of Surgery, 1969, in press. 